\title{
Evaluation of Mechanical Properties of Lightweight Concrete with Pumice Aggregate
}

\author{
Malik Salman Shafiq ${ }^{1}$, Fasih Ahmed Khan ${ }^{2 *}$, Yasir Irfan Badrashi ${ }^{2}$, \\ Fayaz Ahmed Khan ${ }^{2}$, Muhammad Fahim², Asim Abbas², Waqas Adil ${ }^{2}$ \\ 1 CECOS University of I.T. and Emerging Sciences, Peshawar, Pakistan \\ 2 University of Engineering \& Technology, Peshawar, Pakistan \\ * Corresponding author's email: fasihahmad@uetpeshawar.edu.pk
}

\begin{abstract}
This paper presents the findings of a study carried out for evaluation of the mechanical behavior of lightweight concrete. Pumice, a rock resulting from cooling of lava, having entrapped air bubbles, has been used as a lightweight coarse aggregate. Evaluation of the mechanical behavior of the Pumice Lightweight Aggregate Concrete (PLWAC) has been carried out in comparison with the conventional concrete while comparing the mechanical properties of the two. Complete replacement of the coarse aggregate by volume had been carried out in the PLWAC. The testing regime consisted of conducting laboratory tests on concrete samples for evaluation of the mechanical properties including compressive strength, tensile stength, workability and dry density. It was concluded from the results that the use of lightweight aggregate resulted in a reduction in workability, as indicated by the slump test. Moreover, the dry density of PLWAC was also reduced by $30 \%$ as compared to the conventional concrete. A significant decrease (49\%) in the compressive strength of PLWAC as compared to conventional concrete while a minor difference was observed in the tensile strenght of the two (2.9\%). Based on the results of this study, it is recommended that PLWAC cannot be used in structures subjected to heavy loading conditions. However, PLWAC has a good potential to be used in low-cost structures with accompanying benefits of weight reduction.
\end{abstract}

Keywords: lightweight concrete, pumice lightweight aggregate, saline water curing

\section{INTRODUCTION}

Concrete, the second only to water, is the most consumed material on the earth with an estimated annual production is about five billion cubic yards. It is twice of all other building materials used combinedly in construction all over the world. Lightweight concrete (LWC) defined as concrete with a minimum 28 day compressive strength of $17 \mathrm{MPa}$ and an equilibrium density between 1120 and $1920 \mathrm{~kg} / \mathrm{m}^{3}$ [1]. Such lower density of lightweight structural concrete significantly reduces structural weight and concrete member sizes which in turn minimize the cost of the project, transportation, and foundation design $[2 \div 5]$. Lightweight aggregate concrete, made from natural volcanic materials, was used 2000 years ago in the early age of the
Roman empire, however, its use was limited until the early 1900s, when rotary-kiln-produced expanded shale and clay aggregate lightweight concrete used in ship construction. Lightweight aggregates (LWAs) now days are naturally available as pumice and scoria while shales, clays, slates, fly ashes, or blast-furnace slags are artificially manufactured in plants.

Research had been focused on the performance of lightweight aggregates concreted such as expanded clay aggregate, lightweight crushed bricks, starch-based aggregate, palm oil shells

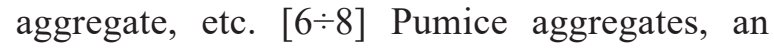
alumino-silicate of volcanic origin, formed on rapid solidification of gas-rich glassy lava, have been used since last decades in the production of lightweight concrete. 
Pumice aggregates gradation and addition of admixtures simultaneously have shown significant improvement in compressive strength, density, and workability of concrete [3]. Pumice aggregate to cement ratio has a significant effect on strength, particularly, when properly graded aggregates are used. For well-graded pumice aggregates, higher aggregate to cement ratio's gives comparable strength to that of two graded aggregates used with lower aggregate to cement ratio $[4,9]$.

Lightweight aggregates are highly porous, when used in concrete, resulted in higher water absorption thus reducing the workability as compared to normal weight aggregate [11]. The workability of lightweight aggregate concrete was improved by pre-wetting aggregates before mixing in concrete. The influence of pre-witting time of lightweight aggregate on the workability of concrete, in the absence of water-reducing admixture, along with partial replacement of cement by Fly Ash was investigated. It was concluded that soaking of aggregates for an optimum time of 30-minutes and replacement of cement with Fly Ash up to 30\%, significantly improved the workability and strength of lightweight aggregate concrete [12]. Different prewitting methods investigated lead to the conclusion that vacuum-soaking and water-soaking of lightweight aggregates before mixing improved the workability and compressive strength [1].

The development of concrete strength is directly affected by curing time. Prolonged curing has significantly increased the strength of, same batch concrete, compared to short-duration curing. (Gonnerman and Shuman 1928). The use of saline water for the curing of concrete was investigated $[13,14]$. The effect of saline water curing of normal weight concrete for different ages was studied. It was concluded, long-duration curing with saline water reduces strength up to $30 \%$ compare to curing with fresh water. However, for a short duration, strength was not significantly reduced. In literature, barely a study was conducted on the use of saline water for the curing of lightweight aggregate concrete.

Many researchers have reported research works on lightweight concrete with pumice aggregates $[2,15 \div 21]$. Limited research is available for the evaluation of PLWAC when cured with water that contains sodium sulphate solution. The main objective of this research is to check the compressive strength of concrete when aggregate is replaced with pumice. To check and investigate the effects of salty curing water on the compressive strength of normal concrete and pumice concrete.

\section{MATERIAL AND METHODS}

\section{Materials}

The cement that was used in the research was ASTM type 1 [22] cement locally available in Pakistan with a brand name of "Kohat Cement". The cement is manufactured by the Kohat cement factory in Pakistan. It contains $95 \%$ clinker and $5 \%$ gypsum content, with a specific gravity according to ASTM C187 [23] and fineness according to ASTM C786 [24] were found to be 3.15 and $99 \%$ (passing through sieve \#200) respectively. The chemical and physical properties for the cement used is given in Table 1.

Table 1. Chemical and physical properties of Kohat cement

\begin{tabular}{|c|c|c|c|c|c|}
\hline \multicolumn{3}{|c|}{ Chemical } & \multicolumn{4}{c|}{ Physical } \\
\hline Item & $\begin{array}{c}\text { ASTM C150 } \\
\text { spec. limits [23] }\end{array}$ & Test result (\%) & Item & $\begin{array}{c}\text { ASTM C150 } \\
\text { spec. limits [23] }\end{array}$ & Test result \\
\hline $\mathrm{SiO}_{2}$ & Not applicable & 20.78 & Blaine fineness $\left(\mathrm{m}^{2} / \mathrm{kg}\right)$ & $430 \mathrm{max}$ & 315 \\
\hline $\mathrm{Al}_{2} \mathrm{O}_{3}$ & 6.0 max & 5.81 & $\begin{array}{c}\text { Compressive } \\
\text { strength (MPa) }\end{array}$ & min & 14 \\
\hline $\mathrm{Fe}_{2} \mathrm{O}_{3}$ & 6.0 max & 2.99 & 3 days & 7 & 26 \\
\hline $\mathrm{CaO}$ & Not applicable & 62.18 & 7 days & 28 & 45 \\
\hline $\mathrm{MgO}$ & 6.0 max & 1.52 & 28 days & - & - \\
\hline $\mathrm{SO}_{3}$ & 3.0 max & 1.89 & $\begin{array}{c}\text { Time of setting } \\
\text { (minutes)(vicat) }\end{array}$ & 45 & 145 \\
\hline Ignition loss & 3.5 max & 2.31 & Initial not less than & 375 & 240 \\
\hline Insoluble residue & 1.5 max & 0.75 & Not more than & - & - \\
\hline Free limestone & 5.0 max & 0.68 & - & & 28 \\
\hline
\end{tabular}




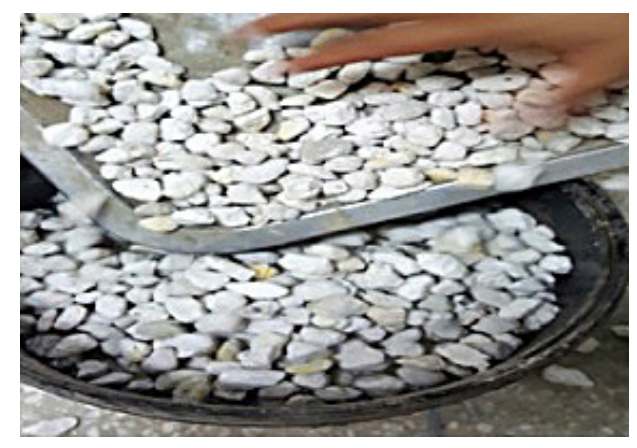

Fig. 1. Pumice aggregate

Pumice aggregate was obtained from Rabbani \& Sons, Lahore, Pakistan. It was used as a coarse aggregate in preparation for the concrete mixes. Pumice aggregate used was having a maximum size of 20 $\mathrm{mm}$ and a Nominal maximum size of $15 \mathrm{~mm}$ as can be seen in Figure 1. The chemical and physical properties of pumice aggregate are shown in Table 2. The silica $\left(\mathrm{SiO}_{2}\right)$ content is quite high which indicates the type of pumice is acidic. For the construction sector, acidic type pumice is preferred [25].

The sand was from a local source of Lawrencepur, located in Pakistan. The sand fineness modulus was calculated to 2.5 as per ASTM C136 [26]. The available moisture absorption (\%), available moisture content (\%), bulk specific gravity $(\mathrm{g} / \mathrm{cc})$, and apparent specific gravity $(\mathrm{g} / \mathrm{cc})$ were calculated using ASTM C127 [27] and was found to be $8.6,1.25,2.68$ and 2.7 respectively. To check the sand for organic impurities the sand was tested and it observed lighter color when compared with the standard solution prepared as per ASTM C87 [28].

For the preparation of mixes as well as curing purpose of the concrete the water used is clean and portable. This is also suitable for human drinking and washing purpose. All standards of ASTM 1602 [29] were taken into consideration while selecting the source of water.

\section{Concrete mixtures composition}

For this research work,mixes containing pumice as coarse aggregate were prepared. For the concrete mix preparation 1:2:4 ratio. Every mix had the same water to cement ratio of 0.5 .

\section{Slump test}

To check the workability of the concrete prepared from pumice aggregate slump test was performed in accordance to ASTM-C143 [30].

\section{Unit weight}

The unit weight of PLWAC was found after measuring the weight of standard concrete cylinder having a volume of $0.0056 \mathrm{~m}^{3}$. The weight of each cylinder was measure with the help of digital weigh balance.

\section{COMPRESSIVE STRENGTH}

The cylinder specimens for compression tests were prepared and tested as per ASTM C470 [31] and ASTM C39 [32] respectively. A Standard $152.4 \mathrm{~mm}$ diameter and $304.8 \mathrm{~mm}$ height cylinder molds were used. A total 50 cylinders were casted, and were cured for 3, 7, 14 and 28 days in potable/ drinking water in accordance to ASTM C192 [33].

\section{Durability study (sulphate attack)}

After casting of the concrete specimens, they were demolded and were set for curing under three different groups. These groups were placed in different tanks having following sulphate concentration.

1) $1 \%$ Solution of $\mathrm{Na}_{2} \mathrm{SO}_{4}$,

2) $3 \%$ Solution $\mathrm{Na}_{2} \mathrm{SO}_{4}$,

3) $5 \%$ Solution $\mathrm{Na}_{2} \mathrm{SO}_{4}$.

The specimens were left for 27 days in sodium sulphate exposure. The effect of sulphate concentration on the performance of normal and pumice aggregate concrete cements was evaluated by measuring the reduction in compressive strength.

\section{RESULTS}

\section{Slump test}

The results are presented in Figure 2, with the replacement of aggregate with $100 \%$ light weight pumice aggregate the slump value decreased $11 \%$. The decrease in the slump value of PLWAC is due to high rate of absorption of the pumice aggregate as shown in Table 2. The pumic aggrgate has a lesser density as compared to normal aggregate due to which PLWAC slump value is not as much as normal density concrete with has the same workability [34].

\section{Unit weight}

The unit weight of CM was $2401 \mathrm{~kg} / \mathrm{m}^{3}$ and PLWAC was having a $1674 \mathrm{~kg} / \mathrm{m}^{3}$ (Figure 3). A 


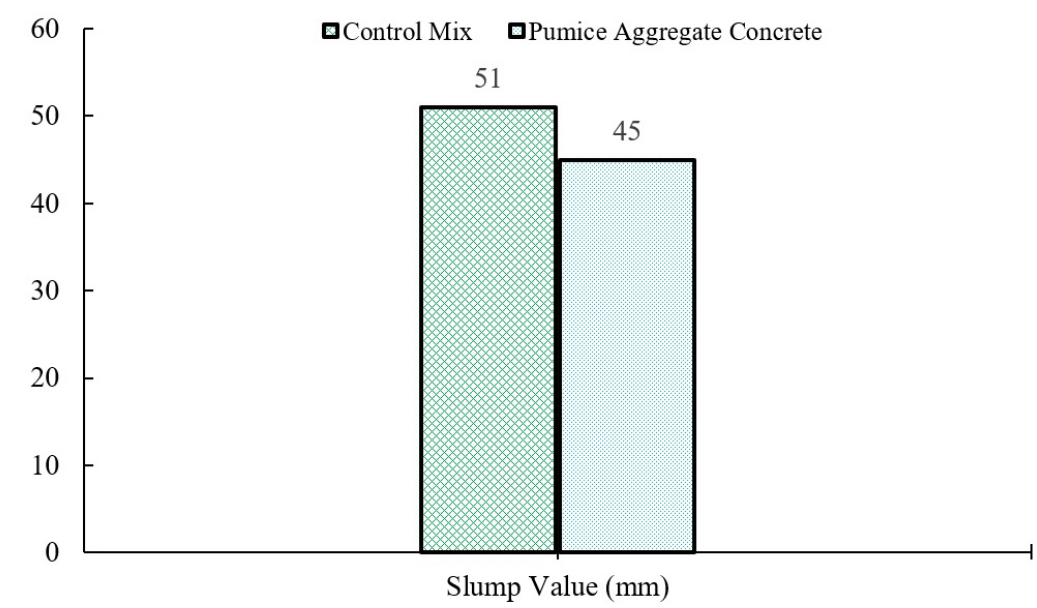

Fig. 2. Slump test of fresh concrete

Table 2. Pumice chemical and physical properties

\begin{tabular}{|c|c|c|c|}
\hline \multicolumn{2}{|c|}{ Chemical analysis } & \multicolumn{2}{c|}{ Physical properties of pumice aggregate } \\
\hline Element (\%) & Pumice & Item & Standard [28] \\
\hline $\mathrm{SiO}_{2}$ & 71.75 & Bulk specific gravity & 1.36 \\
\hline $\mathrm{Al}_{2} \mathrm{O}_{3}$ & 12.33 & Apparent specific gravity & 28.80 \\
\hline $\mathrm{Fe}_{2} \mathrm{O}_{3}$ & 1.98 & Water absorption (\%) & - \\
\hline $\mathrm{FeO}$ & 0.02 & - & - \\
\hline $\mathrm{MgO}$ & 0.12 & - & - \\
\hline $\mathrm{CaO}$ & 0.7 & - & - \\
\hline $\mathrm{Na}_{2} \mathrm{O}$ & 3.59 & - & - \\
\hline $\mathrm{K}_{2} \mathrm{O}$ & 4.47 & - & - \\
\hline $\mathrm{MnO}^{\mathrm{TiO}}$ & 0.07 & - & - \\
\hline $\mathrm{P}_{2} \mathrm{O}_{5}$ & 0.11 & - & - \\
\hline $\mathrm{SO}_{3}$ & 0.008 & - & - \\
\hline $\mathrm{H}_{2} \mathrm{O}$ & 0.18 & - & \\
\hline
\end{tabular}

reduction $727 \mathrm{~kg}$ was observed, which makes $30 \%$ reduction in the unit weight of the PLWAC when compared with conventional concrete.

\section{COMPRESSIVE STRENGTH}

The results of compression tests on concrete cylinders are shown in Figure 4. Compressive strength result at 28 days shows that when pumice aggregate is used in concrete as a replacement for coarse aggregate and cured in normal water, the compressive strength dropped by $50 \%$. The decease of strength at as observed at various days of testing is shown in Figure 5. The initial gain of strength of CM and PLWAC was similar but with the increase of time, the strength gain of PLWAC reduce by $50 \%$.

\section{Normal concrete compressive strength under different curing solutions}

The effect of the different concentration of sodium sulphate solution curing on the compressive strength was observed up to 28 days. The was a clear decrease of compressive strength observed with the increase in the sodium sulphate solution concentration as reported in Table 3. The decrease in the compressive strength was dominate up to 14 days of testing but on the 28 days of curing the decrease in the strength was reduced only to 1 percent approximately. A maximum of 12.8 percent of strength was observed at 7 days of testing, which indicates that sodium sulphate solution concentration in the concrete in the curing water can decrease the initial strength gain but has a very small effect on the final strength gain on the normal strength concrete as can be seen in Fig. 6 . 


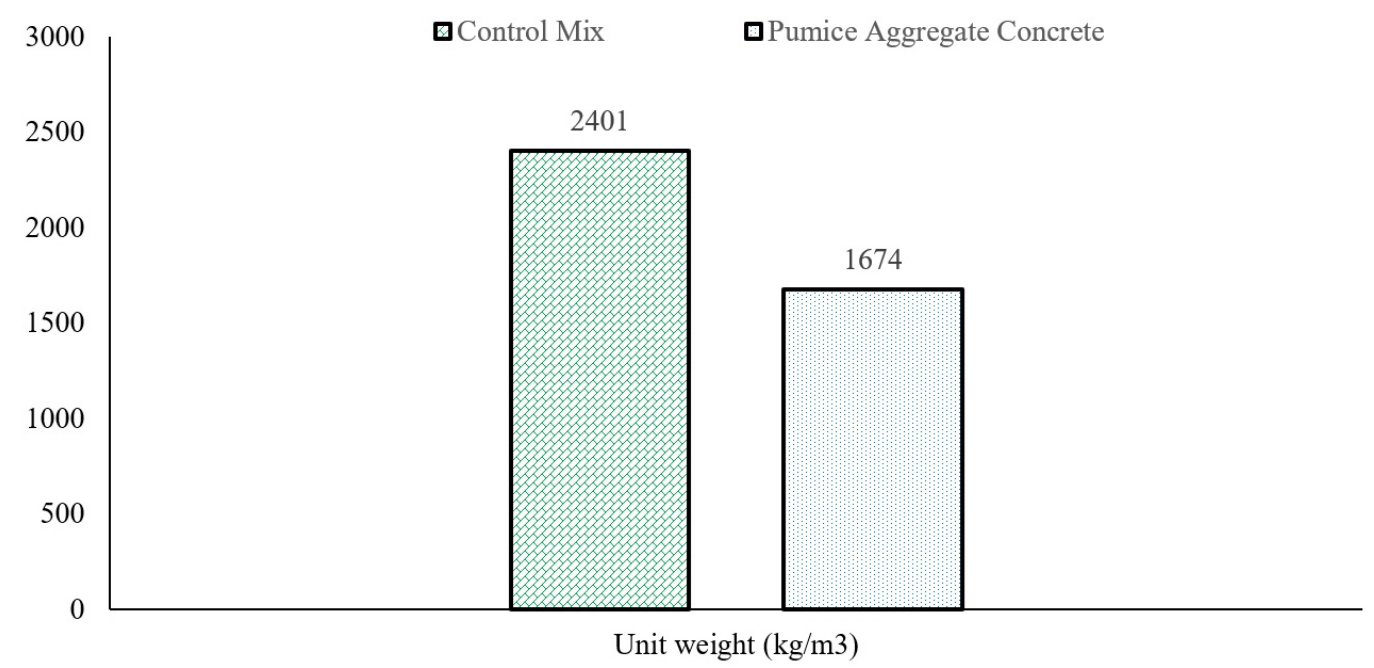

Fig. 3. Unit weight of PLWAC in comparison with normal concrete

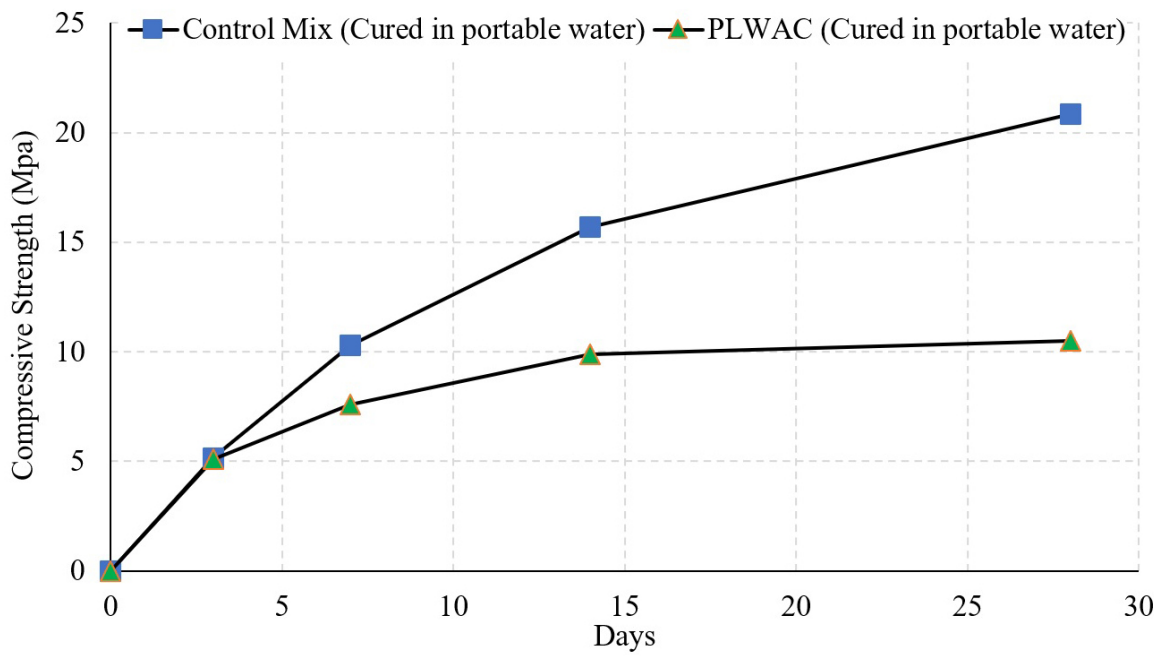

Fig. 4. Compressive strength of CM and PLWAC cured with portable water

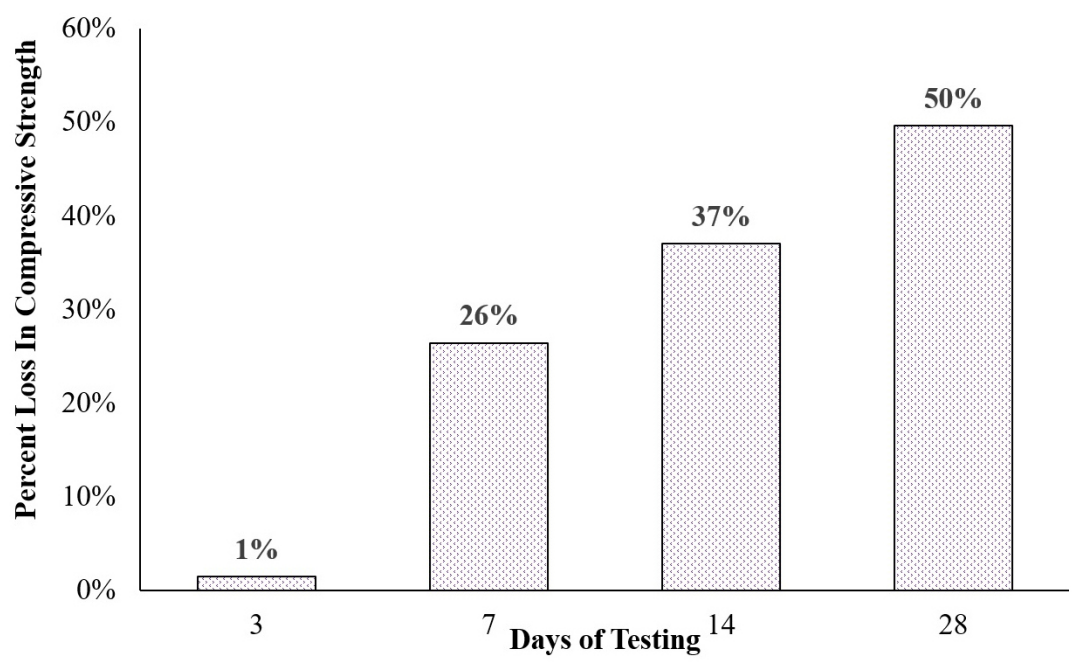

Fig. 5. Percentage loss of compressive strength of PLWAC 
Table 3. Normal concrete compressive strength, (fc') MPa under different concentration of sodium sulphate solution

\begin{tabular}{|c|c|c|c|c|}
\hline \multirow{4}{*}{ Days } & \multicolumn{4}{|c|}{ Normal concrete } \\
\cline { 2 - 5 } & Under portable water curing & $1 \%$ Solution curing & $3 \%$ Solution curing & $5 \%$ Solution curing \\
\hline 3 & 5.2 & 5.0 & 4.8 & 4.7 \\
\hline 7 & 10.3 & 9.7 & 9.1 & 9.0 \\
\hline 14 & 15.7 & 15.0 & 14.1 & 13.9 \\
\hline 28 & 20.9 & 20.8 & 20.7 & 20.7 \\
\hline
\end{tabular}

Table 4. PLWAC compressive strength, (fc') MPa under different concentration of sodium sulphate

\begin{tabular}{|c|c|c|c|c|}
\hline \multicolumn{4}{|c|}{ PLWAC } \\
\hline \multirow{2}{*}{ Days } & \multicolumn{4}{|c|}{ Compressive strength (MPa) } \\
\cline { 2 - 5 } & Under portable water curing & $1 \%$ Solution curing & $3 \%$ Solution curing & $5 \%$ Solution curing \\
\hline 3 & 5.1 & 4.6 & 4.3 & 4.3 \\
\hline 7 & 7.6 & 7.4 & 5.8 & 5.3 \\
\hline 14 & 9.9 & 7.8 & 7.2 & 6.3 \\
\hline 28 & 10.5 & 10.4 & 10.3 & 10.3 \\
\hline
\end{tabular}

\section{PLWAC Compressive strength under different curing solutions}

The effect of the different concentration of sodium sulphate solution curing on the compressive strength was observed up to 28 days for PLWAC. The compressive strength showed a decrease with the incorporation of pumice aggregate. There was further decrease observed, when cured in sodium sulphate solution. The was a clear decrease of compressive strength observed with the increase in the sodium sulphate solution concentration as reported in Table 4. The decrease in the compressive strength was dominate up to 14 days of testing but on the 28 days of curing the decrease in the strength was reduced only to 1 percent approximately. A maximum of 36.1 percent of strength was observed at 14 days of testing, which indicates that sodium sulphate solution concentration in the concrete in the curing water can decrease the initial strength gain but has a very small effect on the final strength gain on the normal strength concrete as can be seen in Figure 7.

\section{Split tensile strength.}

The specimens were tested for split tensile strength at 28 days. The result of split tensile tests

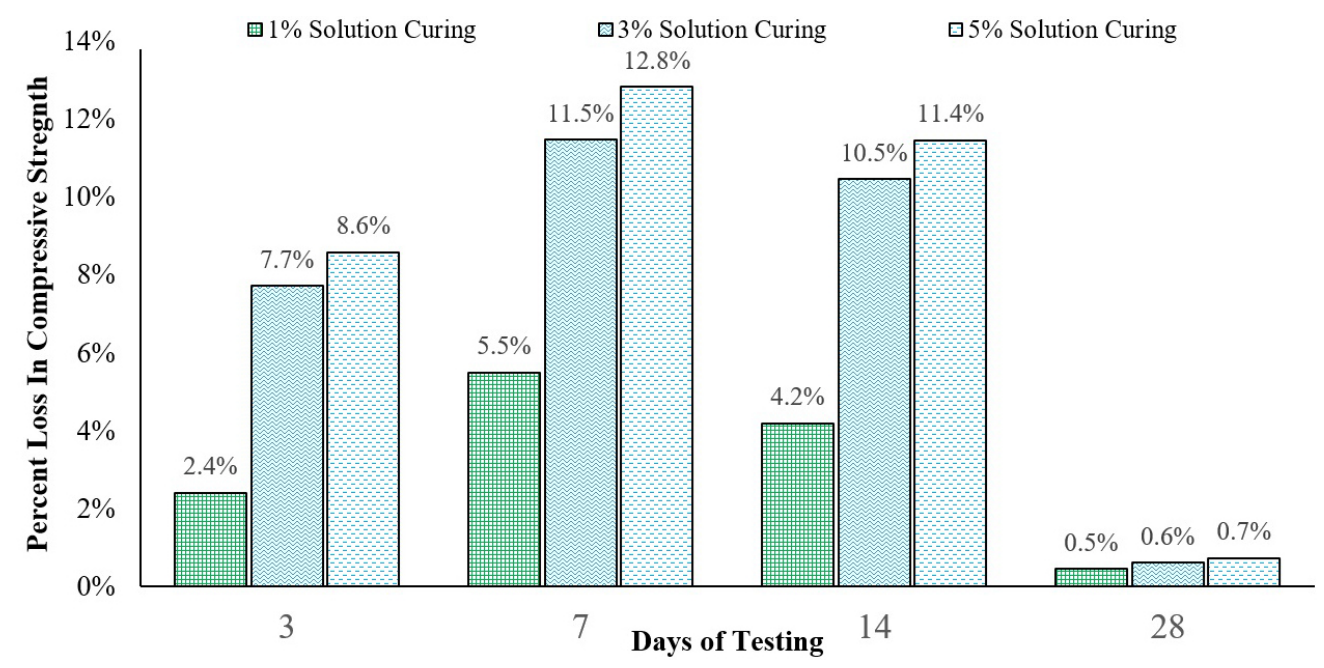

Fig. 6. Percent loss in the compressive strength (fc') of normal concrete under different curing condition of sodium sulphate concentration 
Table 5. Split tensile strength test results

\begin{tabular}{|c|c|c|c|}
\hline Mix type & $\begin{array}{c}\text { Percentage replacement of coarse } \\
\text { aggregate replaced with pumice }\end{array}$ & Average tensile strength (MPa) & $\begin{array}{c}\text { Percent decrease in the } \\
\text { tensile strength }\end{array}$ \\
\hline CM & 0 & 1.19 & 0 \\
\hline PLWAC & 100 & 1.15 & 3.36 \\
\hline
\end{tabular}

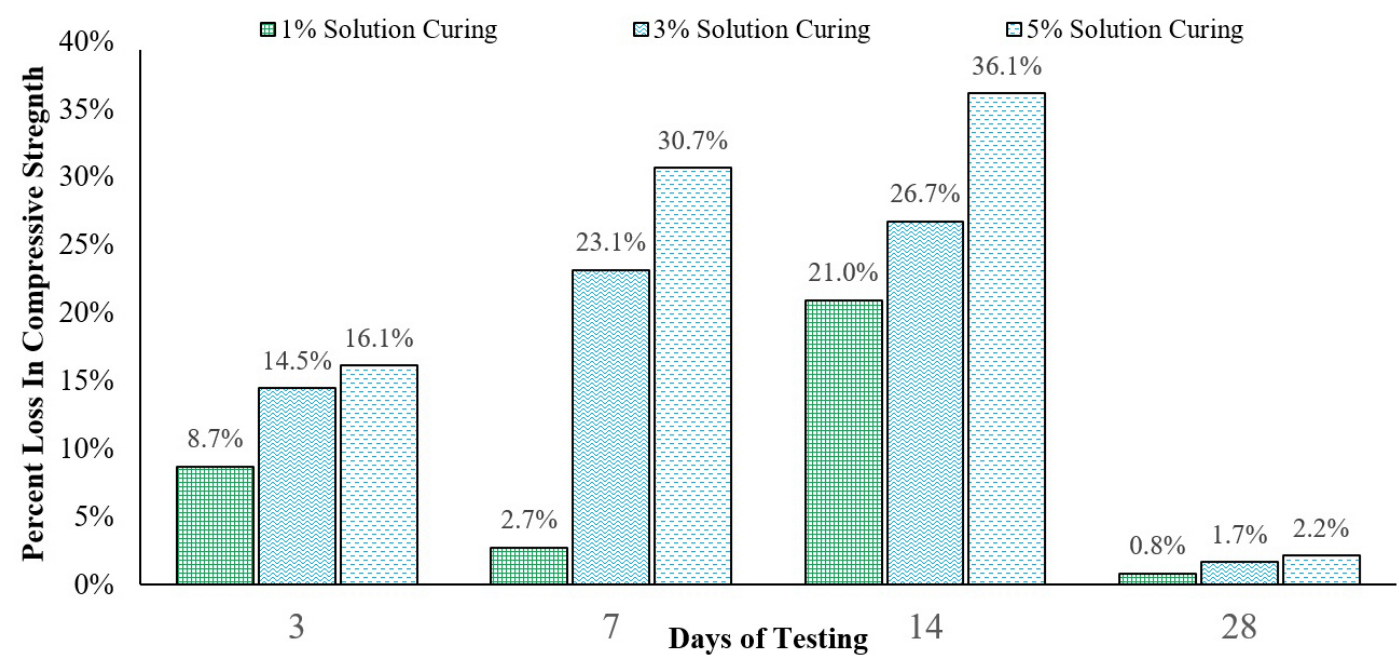

Fig. 7. Percent loss in the compressive strength (fc') of PLWAC under different curing condition of sodium sulphate concentration

on concrete cylinders is shown in Table 5. Split tensile strength of concrete at 28 days is having near values to that of Normal concrete.

\section{CONCLUSIONS}

The following conclusions are drawn from the study carried out to evaluate the suitability of lightweight concrete using Pumice rock.

1. PLWAC when cured in potable water was tested and the result showed $1 \%, 26 \%, 37 \%$ and $50 \%$ drop in its compressive strength at 3 days, 7 days, 14 days, and 28 days, respectively.

2. Normal concrete when cured in potable water having $1 \%$ sodium sulphate solutions showed a compressive strength loss of $2.4 \%, 5.5 \%, 4.2 \%$ and $0.5 \%$ at $3,7,14 \& 28$ days respectively.

3. Normal concrete when cured in potable water having 3\% sodium sulphate solutions showed a compressive strength loss of $7.7 \%, 11.5 \%, 10.5 \%$ and $0.6 \%$ at $3,7,14 \& 28$ days respectively.

4. Normal concrete when cured in potable water having 5\% sodium sulphate solutions showed a compressive strength loss of $8.6 \%, 12.8 \%, 11.4 \%$ and $0.7 \%$ at $3,7,14 \& 28$ days respectively.

5. The maximum strength loss of PLWAC when cured in $1 \%, 3 \%$ and $5 \%$ sodium sulphate solutions was $36.1 \%$ at 14 days at $5 \%$ sodium sulphate solution.

6. After using of $100 \%$ replacement of coarse aggregate with pumice aggregate resulted in 3.36\% decrease in split tensile strength at 28 days.

7. The unit weight of control mix was $2401 \mathrm{~kg} /$ $\mathrm{m} 3$ and PLWAC was $1674 \mathrm{~kg} / \mathrm{m} 3$ which makes it $30 \%$ lighter than the conventional concrete.

8 . From the compressive strength of concrete at 28 days which is below the structural requirement according to ASTM C 330-82a although pumice concrete can be used for insulating purposes, partition walls construction, panel walls in the frame structure, blocks and roof floors etc.

\section{REFERENCES}

1. Kabay N., Aköz F. Effect of prewetting methods on some fresh and hardened properties of concrete with pumice aggregate. Cem. Concr. Compos. 2012, 34(4), 503-507. http://dx.doi.org/10.1016/j. cemconcomp.2011.11.022

2. Manguriu G.N, Mutku R.N., Oyawa W.O, Abuodha S.O. Properties of Pumice Lightweight Aggregate. J Civ. Environ. Res. 2012, 2(10), 58-68. https://iiste. org/Journals/index.php/CER/article/view/3540 
3. Sari D., Pasamehmetoglu A.G. The effects of gradation and admixture on the pumice lightweight aggregate concrete. Cem Concr Res. 2005, 35(5), 936-942.

4. Gündüz L. The effects of pumice aggregate/cement ratios on the low-strength concrete properties. Constr Build Mater. 2008, 22(5), 721-728.

5. Rico S., Farshidpour R., Tehrani F.M. State-of-theart report on fiber-reinforced lightweight aggregate concrete masonry. Adv. Civ. Eng. 2017, Article ID 8078346, 1-9. https:/www.hindawi.com/journals/ ace/2017/8078346/

6. Alduaij J, Alshaleh K, Naseer Haque M, Ellaithy $\mathrm{K}$. Lightweight concrete in hot coastal areas. Cem Concr Compos. 1999, 21(5-6), 453-458.

7. Glenn G.M/, Gray G.M/, Orts W.J., Wood D.W. Starch-based lightweight concrete: Effect of starch source, processing method, and aggregate geometry. Ind Crops Prod. 1999, 9(2), 133-144.

8. Basri H.B., Mannan M.A., Zain M.F.M. Concrete using waste oil palm shells as aggregate. Cem Concr Res. 1999, 29(4), 619-622.

9. Gündüz L., Uğur I. The effects of different fine and coarse pumice aggregate/cement ratios on the structural concrete properties without using any admixtures. Cem Concr Res. 2005, 35(9), 1859-1864.

10. Uysal H., Demirboga R., Şahin R, Gül R. The effects of different cement dosages, slumps, and pumice aggregate ratios on the thermal conductivity and density of concrete. Cem Concr Res. 2004, 34(5), 845-848.

11. Chen B., Liu J. Contribution of hybrid fibers on the properties of the high-strength lightweight concrete having good workability. Cem Concr Res. 2005, 35(5), 913-917.

12. Lo T.Y., Cui H.Z., Li Z.G. Influence of aggregate prewetting and fly ash on mechanical properties of lightweight concrete. Waste Manag. 2004, 24(4), 333-338.

13. Wegian F.M. Effect of seawater for mixing and curing on structural concrete. IES J Part A Civ Struct Eng. 2010, 3(4), 235-243. http://www.tandfonline. com/doi/abs/10.1080/19373260.2010.521048

14. Guo Q., Chen L., Zhao H., Admilson J., Zhang W. The effect of mixing and curing sea water on concrete strength at different ages. MATEC Web Conf. 2018, 142, 1-6.

15. Parhizkar T., Najimi M., Pourkhorshidi A.R. Application of pumice aggregate in structural lightweight concrete. Asian J Civ Eng. 2012, 13(1), 43-54. https://www.researchgate.net/publication/258511411

16. Anwar Hossain K.M., Ahmed S. Lightweight concrete incorporating volcanic ash-based blended cement and pumice aggregate. J Mater Civ Eng. 2011, 23(4), 493-498. http://ascelibrary.org/doi/10.1061/ \%28ASCE\%29MT.1943-5533.0000180
17. Anwar Hossain K.M. Properties of volcanic pumice based cement and lightweight concrete. Cem Concr Res. 2004, 34(2), 283-291. http://linkinghub.elsevier.com/retrieve/pii/S0008884603002825

18. Green S.M.F., Brooke NJ, McSaveney LG, Ingham JM. Mixture Design Development and Performance Verification of Structural Lightweight Pumice Aggregate Concrete. J Mater Civ Eng. 2011, 23(8), 1211-1219. http://ascelibrary.org/doi/10.1061/\%2 8ASCE\%29MT.1943-5533.0000280

19. Yohannes M. Investigation on the suitability of pumice and scoria aggregates in ribbed-slab construction. 2015, 5(4), 75-82.

20. Karahan O., Hossain K.M.A., Atis C.D., Lachemi M., Ozbay E. Ground granulated pumice-based cement mortars exposed to abrasion and fire. Arab J Sci Eng. 2017, 42(3), 1321-1326. http://link. springer.com/10.1007/s13369-016-2403-0

21. Spratt B.H. Lightweight aggregate concrete. Civ Eng London. 1984, 2, 44-55.

22. ASTM C150/C150M - 19a. Standard specification for portland cement. ASTM Int West Conshohocken, USA. 2019.

23. ASTM C187 - 16. Standard Test Method for Amount of Water Required for Normal Consistency of Hydraulic Cement Paste. ASTM Int West Conshohocken, USA. 2016.

24. ASTM C786 / C786M-17. Standard Test Method for Fineness of Hydraulic Cement and Raw Materials by the $300-\mu \mathrm{m}$ (No. 50), 150- $\mu \mathrm{m}$ (No. 100), and $75-\mu \mathrm{m}$ (No. 200) Sieves by Wet Methods. ASTM Int West Conshohocken, USA. 2017.

25. Dogan-Saglamtimur N., Guven A., Bilgil A. Physical and mechanical properties of cemented ashbased lightweight building materials with and without Pumice. Adv Mater Sci Eng. 2018, Article ID 9368787. https://www.hindawi.com/journals/ amse/2018/9368787/

26. ASTM C136 / C136M - 19. Standard test method for sieve analysis of fine and coarse aggregates. ASTM Int West Conshohocken, USA. 2019.

27. ASTM C127-15. Standard test method for relative density (specific gravity) and absorption of coarse aggregate. ASTM Int West Conshohocken, USA. 2015.

28. ASTM C87/C87M - 17. Standard test method for effect of organic impurities in fine aggregate on strength of mortar. ASTM Int West Conshohocken, USA. 2017.

29. ASTM C1602 / C1602M-18. Standard specification for mixing water used in the production of hydraulic cement concrete. ASTM Int West Conshohocken, USA. 2018.

30. ASTM C143/C143M-15a. Standard test method for slump of hydraulic-cement concrete. ASTM Int West Conshohocken, USA. 2015. 
31. ASTM C470 / C470M-15. Standard specification for molds for forming concrete test cylinders vertically. ASTM Int West Conshohocken, USA. 2015.

32. ASTM C39/C39M-18. Compressive strength of cylindrical concrete specimens. ASTM Int West Conshohocken, USA. 2018.
33. ASTM C192 / C192M-19. Standard practice for making and curing concrete test specimens in the laboratory. ASTM Int West Conshohocken, USA. 2019.

34. Hossain K.M.A. Development of volcanic pumice based cement and lightweight concrete. Mag Concr Res. 2004, 56(2), 99-109. 